\title{
Value Investment Theory and Investment Suggestion in Foreign Healthcare Industry--Taking Pfizer, Novartis, and Merck as examples
}

\author{
Shengxi Bai ${ }^{1, *}$ \\ ${ }^{1}$ The High School Affiliated to Beijing Normal University \\ *Corresponding author. Email; guanghua.ren@gecacdemy.cn
}

\begin{abstract}
Value investment is a mainstream investment method in the stock market. Through the value investment theory, this paper selects three listed companies in the Healthcare industry in the United States, namely Pfizer, Novartis, and Merck. Then, the companies' stocks are compared from three aspects, including risk, profitability, and market value. The research shows that by comparing the indexes of the stocks of the three listed companies, Pfizer is the strongest stock and is the most valuable one to invest in since it has low risk, high profitability, and relatively good performance in market value relationship. So, investors who are interested in overseas Healthcare industry investment can consider Pfizer as their investment target. After these studies, we believe that stock selection based on value investment theory is feasible for the Healthcare industry in China and abroad. After the full text of the investigation on the stock situation of listed companies related to the Healthcare industry, I hope to make a modest contribution to the development of domestic value investment, enable investors to evaluate the value of listed companies objectively and scientifically, and guide future investment practice. At the same time, it also provides information support to the regulatory institutions of listed companies and the decision-making institutions of industrial development to assist the regulatory practice, which can better promote the prosperity of the real economy in the financial field, guide the better allocation of resources to healthcare, and realize the beautiful blueprint for the healthy development of the Healthcare industry in the future.
\end{abstract}

Keyword: Value Investment, Healthcare Industry, Fundamental Analysis

\section{INTRODUCTION}

The Healthcare industry is an extremely important part of China's national economic development. It is not only related to the long-term stable development of the social economy but also related to people's life and health. The Healthcare industry is known as a "sunrise industry that will never decline" in the investment community, and its development momentum has been more rapid in recent years. With the strong support of national policies in recent years, the biomedical industry has developed very rapidly with the acceleration of urbanization, aging, and many other factors. The biomedical market will undoubtedly be the key area for the development of the Healthcare industry in the future. Therefore, how to help investors obtain long-term and sustainable income through long-term investment in the Healthcare industry through fundamental analysis will become an important issue concerned in practical operation.

\subsection{Journals Reviewed--Theory of Value Investment}

Domestic scholars and foreign scholars have studied value investment for a long time. The theory of value investment originated from the great depression in 1929. At that time, the information of Listed Companies in the market was insufficient and the information asymmetry was serious. Many investment banks and listed companies used this situation to bid up the stock price and obtain income. Insider trading and speculation in the market are serious, and the stock price deviates from the actual value of the stock. Finally, on October 29, 1929, it triggered the American financial crisis [1]. In 1934, Benjamin Graham and David Dodd first put forward the value investment theory in securities analysis [2]. Value investment refers to the investment method of centralized investment and long-term acquisition of excellent enterprises at a price significantly lower than the intrinsic value of stocks, to obtain profits [3]. Value investment is 
to discover and invest undervalued stocks through the concept of basic analysis. The general method of value investment is to compare the intrinsic value of stocks with the current market price, so as to make investment decisions.

Value investment theory is mainly based on the following assumptions:

First, the market is not completely effective. Value investment theory holds that the market is not completely effective and the stock price cannot fully reflect the value of the stock. Therefore, it provides investors with the opportunity to buy stocks at a price lower than the intrinsic value and sell stocks at a price higher than the intrinsic value.

Second, a positive investment strategy can obtain excess profits. A securities investment strategy can be divided into positive investment strategy and negative investment strategy. The traditional investment view holds that the return of securities investment is directly proportional to the risk. However, value investors believe that there is excess return, which is mainly based on the assumption that the market is not completely efficient.

Third, the definition of risk is different. Market volatility is defined as the risk in traditional financial theory. However, value investors believe that volatility may not only lose but also gain. It is inaccurate to define it as risk. Value investment theory holds that the negative factors brought by market fluctuations are the focus of risk control, so the risk should be the possibility of loss [3].

Here are some scholars' classical theories about value investment:

Graham believes that value investment has two characteristics: quantitative analysis and looking for cheap stocks [4]. He believes that the investment value of listed companies can be determined and investment decisions can be made through financial analysis. Graham came up with the "margin of safety" investment method in stock market practice, which refers to the investors' evaluation of the internal value of the target company. When the difference between its internal value and the stock market price reaches a certain degree, they can invest. When using this method to invest in the stock market, investors will make profits when the stock price is far lower than the intrinsic value because the market corrects the wrong pricing; based on inheriting Graham's investment philosophy, Philip Fisher put forward the value investment theory of growth stocks and wrote how to choose growth stocks. Therefore, he is known as the founder of the value investment strategy of growth stocks [5]. Fisher incorporated the factors that can promote the high growth of enterprises into the core competitiveness of enterprises, and paid attention to looking for stocks with high growth in the future. He believes that the evaluation of the company's growth depends on multiple factors, such as R\&D and innovation ability, irreplaceable products or services, management literacy and morality of the management, and other factors that can affect the company's long-term profitability [6]. Warren Buffett further developed Graham's theory; he believes that:

First, choose familiar industries and enterprises to invest in. Investors must know who they are investing in. The investment object must have a simple and clear business model and a sustainable long-term stable business history. Because the simple business model can make investors have a comprehensive and in-depth understanding; Enterprises with sustainable and stable operation history generally have stable long-term cash flow, which is beneficial to evaluate the internal value of enterprises.

Second, follow the principle of safety margin. This is Warren Buffett's inheritance of Graham's classic thought, that is, focusing on the relationship between stock price and intrinsic value. The lower the price, the more likely it is to be worth buying. Buffett pointed out that the socalled intrinsic value can be measured by "discounting all the cash flows that listed companies can generate in the future remaining operating period".

Third, focus on the growth prospects of the enterprise. This is an extension of Fisher's theory by Warren Buffett, who believes that the growth potential of an enterprise is guaranteed by its sustainable competitive advantage. This competitive advantage is related to the franchise, unique market positioning, strong bargaining power, and excellent management.

Fourth, Pay attention to the quantitative analysis of financial statements. Buffett also attaches importance to quantitative analysis of stocks. He believes that the financial statements are a comprehensive reflection of the past and present operation, investment, and financing activities of an enterprise, such as operation, profitability, debt-paying, and so on, from which many things can be found. For example, investors can mine the enterprise's competitive advantage through the return on net assets, operating profit rate, and other indicators, and judge the internal value of the enterprise by examining the cash flow [5].

In the past five years, Chinese scholars have also done some research on value investment. Jianhuan Huang, Liqin Pan, and Haitao Song believed that Chinese stock investors pay attention to value investment and put forward that the focus of investor education should not be on value concept [7]. Chinese investors do not lack the concept of value investment, but the environment conducive to value investment. Therefore, the key is to improve the market environment and establish a capital market conducive to value investment. At the same time, we should also improve the awareness of dividend returns of listed companies and strengthen information 
disclosure and supervision based on the index of cumulative dividend financing ratio. Gan Weiming and Zhang Dixin believe that speculation still exists in China's capital market, but value investment based on profit and growth is still effective [8]. Therefore, on the one hand, we should guide and improve the quality of listed companies, on the other hand, to strengthen the basic functions of the market, we need to establish an efficient information disclosure system, improve information transparency and reduce adverse selection risk, to improve the overall resource allocation efficiency of the domestic capital market and promote the long-term development of China's capital market [8]. In addition, for individual investors, Peng Xiaojie believes that we should adhere to the concept of value investment, longterm investment and responsible investment, ensure the allocation of the secondary industry as the leading and innovative industry, reasonably and moderately adjust the holding period of stock asset portfolio products, improve the risk management ability and withdraw sufficient risk management reserves [9].

At present, there is little research on the value investment of the Healthcare industry in China. Although the Healthcare industry rises rapidly in recent years, there is almost no relevant literature. And those relevant literatures only focus on the domestic Healthcare industry and domestic Healthcare companies. There is no useful information for investors who want to invest Healthcare industry abroad. This paper focuses on the actual situation to make up for the lack of research on the value investment of the foreign Healthcare industry in China and provides index stock selection suggestions for investors.

\section{DATA \& METHOD}

\subsection{Data}

The data used in this paper is from Yahoo Finance. Three companies' stocks, Pfizer, Novartis, and Merck are taken as the research sample. The sample period of this paper is from December 2017 to December 2020. The data involved in the research mainly include 2 categories. One category is stock trading data: including the return rate, beta, momentum, dividend yield, $\mathrm{P} / \mathrm{E}$ ratio, $\mathrm{P} / \mathrm{B}$ ratio, PEG ratio, and market value of each stock. The other is the financial data of listed companies: including the shareholders' equity, current ratio, quick ratio, debt ratio, market cap, profit margin, assets turnover ratio, net earnings, ROA, and ROE of all listed companies involved in the sample. The above financial indicators are the annual report data of the financial statements of each listed company.

\subsection{Method}

\subsubsection{Risk Ratio}

\subsubsection{Current Ratio}

Current ratio is also known as the working capital ratio or real Ratio [10]. It refers to the ratio of current assets to the current liabilities of an enterprise. It is an index reflecting the short-term solvency of enterprises.

$$
\text { CurrentRatio }=\frac{\text { CurrentAssets }}{\text { CurrentLiabilities }}
$$

\subsubsection{Quick Ratio}

Quick ratio refers to the ratio of quick assets to current liabilities. It measures the ability of an enterprise's current assets to be immediately realized and used to repay current liabilities.

$$
\text { QuickRatio }=\frac{\text { CurrentAssets }- \text { Inventory }}{\text { CurrentLiabilities }}
$$

\subsubsection{Debt Asset Ratio}

Debt Asset ratio is the percentage of total liabilities to total assets of an enterprise. This index reflects the proportion of assets provided by creditors in all assets of the enterprise, the risk degree of creditors providing credit funds to the enterprise, and the ability of enterprises to borrow money.

$$
\text { DebtAssetRatio }=\frac{\text { TotalAssets }- \text { TotalEquity }}{\text { TotalAssets }}
$$

\subsubsection{Debt-to-Equity Ratio}

Debt to equity ratio, also known as debt to owner's equity ratio, is an indicator to measure the company's financial leverage, that is, it shows the ratio of equity to debt in the capital source of the company's assets [11]. It can be used to show whether a company's borrowing is too high compared with shareholders' equity.

$$
\text { Debt }- \text { to }- \text { EquityRatio }=\frac{\text { TotalDebt }}{\text { TotalEquity }}
$$

\subsubsection{Market Cap}

Market Capitalization is the total value of a company's securities as quoted on a stock exchange. It can also denote the total value of all the securities listed on a stock exchange, or the total value of one sector of a market's listed securities. 


\section{MarketCap $=$ Price $\times$ TotalShares}

\subsubsection{Beta}

Beta coefficient is a tool to evaluate the systemic risk of securities, which is used to measure the volatility of a securities or an investment portfolio relative to the overall market.

$$
\beta_{a}=\rho_{a m} \times \frac{\sigma_{a}}{\sigma_{m}}
$$

Or

$$
\beta_{a}=\frac{\operatorname{Cov}\left(r_{a}, r_{m}\right)}{O_{m}^{2}}
$$

\subsubsection{Profitability Ratio}

\subsubsection{Total Assets Turnover Ratio}

Asset turnover ratio is an important financial ratio to measure the efficiency of enterprise asset management [12]. This indicator is usually defined as the ratio of sales revenue to average total assets, which reflects the flow speed of all assets from input to output during the operation period of the enterprise, and reflects the management quality and utilization efficiency of all assets of the enterprise.

$$
\text { TotalAssetsTurnoverRatio }=\frac{\text { Sales }}{\text { TotalAssets }}
$$

\subsubsection{Profit Margin}

Profit margin is one of the commonly used profitability ratios to gauge the degree to which a company or a business activity makes money. It represents what percentage of sales has turned into profits.

$$
\text { ProfitMargin }=\frac{\text { NetIncome }}{\text { Sales }}
$$

\subsubsection{Return on Assets (ROA) Ratio}

Return on assets is an indicator used to measure how much net profit each unit of assets creates.

$$
R O A=\frac{\text { NetIncome }}{\text { TotalAssets }}
$$

\subsubsection{Return on Equity (ROE) Ratio}

Return on equity is an accounting calculation method similar to return on investment. It is an indicator used to evaluate the profitability of a company and can be used as an ownership indicator to compare the profitability of different enterprises in the same industry [12].
$R O E=$ ProfitMargin $\times$ TotalAssetsTurnover $\times$ EquityMultiplier

Or

$$
R O E=\frac{\text { NetIncome }}{\text { AverageCommonShareholder'sEquity } . . .}
$$

\subsubsection{Net Earnings}

Net Earnings refers to the retained profits of the company after paying income tax following the regulations in the total profits, which is generally called after-tax profit or net income.

\subsubsection{Market Ratio}

\section{$\underline{\text { 2.2.3.1 Price-to-Earning (P/E) Ratio }}$}

The price-to-earnings ratio ( $\mathrm{P} / \mathrm{E}$ ratio) is the ratio for valuing a company that measures its current share price relative to its per-share earnings (EPS) [10]. The price-toearnings ratio is also sometimes known as the price multiple or the earnings multiple [9].

$$
\text { Price }- \text { to }- \text { EarningRatio }=\frac{\text { EarningsPerShare }}{\text { MarketValuePerShare }}
$$

\subsubsection{Price-to-Book (P/B) Ratio}

Companies use the price-to-book ratio ( $\mathrm{P} / \mathrm{B}$ ratio) to compare a firm's market capitalization to its book value [10].

$$
\text { Price }- \text { to }- \text { BookRatio }=\frac{\text { BookValuePerShare }}{\text { MarketPricePerShare }}
$$

\subsubsection{Dividend Yield}

The dividend yield is the ratio of dividend to stock price. In investment practice, the dividend yield is one of the important yardsticks to measure whether an enterprise has investment value.

$$
\text { DividendYield }=\frac{D}{P_{o}} \times 100 \%
$$

Or

$$
\text { DividendYield }=\frac{\text { CashDividendPerShare }}{\text { CurrentMarketPricePerShare }}
$$

\subsubsection{Price/Earning-to-Growth (PEG) Ratio}

PEG Ratio is the value obtained by dividing the P/E ratio of listed companies by profit growth rate [11]. This index can not only examine the current financial situation of the company through the $\mathrm{P} / \mathrm{E}$ ratio but can also 
examine the growth expectation of the company in the future through the profit growth rate. Therefore, it is a perfect stock selection reference index.

$$
\text { PEGRatio }=\frac{\text { Price }- \text { to }- \text { EarningRatio }}{\text { GrowthRate }}
$$

\subsubsection{Momentum}

Momentum refers to the ability of stocks (or economic indexes) to grow continuously. Momentum can be regarded as the ratio of the rise and fall of stock prices over some time.

If the 50-Day Moving Average is greater than the 200Day Moving Average, the stock is momentum; if the 50Day Moving Average is smaller than the 200-Day Moving Average, the stock is not momentum.

\subsubsection{Insider Buying}

The purchase of shares of stock in a corporation by someone who is employed by the company.

\section{RESULT AND DISCUSSION}

This paper will analyze the three stocks of three companies from three aspects, Risk, Profitability, and Market Value. This paper will use the data collected from Yahoo Finance and ratios calculated by the formula mentioned above to analyze and compare the quality of each stock and provide index stock selection suggestions for investors.

\subsection{Risk}

The current ratio, quick ratio, debt ratio, debt-toequity ratio, market cap, and beta are the six factors this paper used to analyze the risk of each stock.

Pfizer

Current Ratio $=$ Current Assets/Current Liabilities $=1.48$;

Quick Ratio $=(\mathrm{CA}-\mathrm{INV}) / \mathrm{CL}=1.04$.

Novartis

Current Ratio $=$ Current Assets/Current Liabilities=0.74; Quick Ratio $=(\mathrm{CA}-\mathrm{INV}) / \mathrm{CL}=0.7$.

Merck

Current

Ratio $=$ Current

Assets/Current

Liabilities $=1.02$;

Quick Ratio $=(\mathrm{CA}-\mathrm{INV}) / \mathrm{CL}=0.78$.

So, Pfizer has the highest current ratio and quick ratio, and its current ratio is greater than 1 , which means that it has high liquidity, so its ability to cover its liabilities is stronger than the other two stocks. Merck has the second high current ratio and quick ratio, and its current ratio is also greater than 1, which means it also has a strong ability to cover its debts. However, the quick ratio of Merck is smaller than 1 and smaller than its current ratio. Since the quick ratio is calculated by current assets minus inventory divided by current liabilities, Merck might have more inventory than Pfizer, and its ability to cover its liabilities might not be as strong as we thought. Novartis has the lowest current ratio and quick ratio among the three stocks, and its current ratio is below 1, so its ability to cover its liabilities is weaker than the other two.

Pfizer

Debt Ratio $=$ Total Debt $/$ Total Assets $=0.6$;

Debt-to-Equity Ratio=Total Debt/Total Equity=57.65.

Novartis

Debt Ratio=Total Debt/Total Assets $=0.57$;

Debt-to-Equity Ratio=Total Debt/Total Equity $=74.81$.

Merck

Debt Ratio=Total Debt $/$ Total Assets $=0.72$;

Debt-to-Equity Ratio=Total Debt/Total Equity $=115.58$.

So, in terms of debt, Merck has the highest debt ratio and debt-equity ratio, which means that its debts take a large portion of its total asset. And Novartis has the second high debt ratio. So, its debts also take a big part in its total asset, but smaller than Merck. Pfizer has the lowest debt ratio among the three stocks, which means that its debts take the smallest part of its total asset among the three stocks.

Pfizer

Market Cap $=$ Price $*$ Total Shares $=219.373$ billion;

Novartis

Market Cap=Price*Total Shares=208.149 billion;

Merck

Market cap $=$ Price*Total Shares $=193.348$ billion.

So, all three companies have a large market cap, so all of them are big companies, Merck is relatively smaller than the other two.

Pfizer

$\operatorname{Beta}=\beta_{a}=\frac{\operatorname{Cov}\left(\boldsymbol{r}_{a}, \boldsymbol{r}_{m}\right)}{O_{m}^{2}}=0.67 ;$

Novartis

Beta $=\beta_{a}=\frac{\operatorname{Cov}\left(\boldsymbol{r}_{a}, \boldsymbol{r}_{m}\right)}{\boldsymbol{O}_{m}^{2}}=0.51 ;$

Merck 
Beta $=\beta_{a}=\frac{\operatorname{Cov}\left(r_{a}, \boldsymbol{r}_{m}\right)}{\boldsymbol{O}_{m}^{2}}=0.41$.

So, in terms of beta, all three stocks' $s$ beta is below 1 , which means that all three stocks are below the average market risk, so they are all less risky stocks.

In general, Pfizer has the lowest risk among the three stocks. Although it has a higher beta, it is still below the average market risk, and it has the highest current ratio and quick ratio, so it has excellent ability to cover its liabilities. Also, Pfizer is the largest company among the three stocks, and its debt ratio is relatively small too. Merck has the highest risk because its debts take a large part of its total asset and its ability to cover its liabilities is not that strong. Novartis's risk is between Pfizer and Merck. See Table 1.

Table 1. The Risk of Three Companies' Stocks

\begin{tabular}{llll}
\hline Risk Ratio & $\begin{array}{l}\text { Pfizer Inc. } \\
\text { (PFE) }\end{array}$ & $\begin{array}{l}\text { Novartis } \\
\text { AG (NVS) }\end{array}$ & $\begin{array}{l}\text { Merck \& } \\
\text { Co., Inc. } \\
\text { (MRK) }\end{array}$ \\
\hline $\begin{array}{l}\text { Current } \\
\text { ratio }\end{array}$ & 1.48 & 0.74 & 1.02 \\
$\begin{array}{l}\text { Quick ratio } \\
\text { Debt ratio }\end{array}$ & 1.04 & 0.7 & 0.78 \\
$\begin{array}{l}\text { Debt/Equit } \\
\text { y ratio }\end{array}$ & 57.65 & 74.81 & 115.58 \\
$\begin{array}{l}\text { Market } \\
\text { Cap } \\
\text { Beta }\end{array}$ & $219.373 \mathrm{~B}$ & $208.149 \mathrm{~B}$ & $193.348 \mathrm{~B}$ \\
\hline
\end{tabular}

Data source1: https://finance.yahoo.com

\subsection{Profitability}

Total assets turnover ratio, profit margin, ROA ratio, ROE ratio, and net earnings are the five factors this paper used to analyze the profitability of each stock.

Pfizer

Total assets turnover ratio=Sales/Total Assets $=46407000 / 154229000=0.3$;

Novartis

Total assets turnover ratio=Sales/Total Assets $=49884000 / 132059000=0.4$;

Merck

Total assets turnover ratio $=$ Sales $/$ Total Assets $=42180000 / 118481000=0.36$.

So, Novartis has the highest total asset turnover ratio, which means that it has the highest asset utilization. Merck and Pfizer have similar total asset turnover, so their asset utilization is similar but relatively weaker than the Novartis.

Pfizer
Profit margin $=$ Net Income $/$ Sales $=24 \%$;

Novartis

Profit margin=Net Income/Sales $=15.59 \%$;

Merck

Profits margin $=$ Net Income/Sales $=14.63 \%$.

In terms of the profit margin, Pfizer has the highest profit margin so its profitability is the highest. Novartis has the second high-profit margin, so its profitability is also pretty good. Merck has the relatively lowest profit margin, so its profitability is relatively smaller than the other two.

Pfizer

$\mathrm{ROA}=\mathrm{Net}$ Income $/$ Total Assets $=0.07$;

ROE=Profit Margin*Total Assets Turnover*Equity Multiplier $=0.24 * 0.3 * 2.43=0.170$.

Novartis

$\mathrm{ROA}=\mathrm{Net}$ Income $/$ Total Assets $=0.06$;

ROE=Profit Margin*Total Assets Turnover*Equity Multiplier $=0.15 * 0.4 * * 2.3=0.138$.

Merck

$\mathrm{ROA}=\mathrm{Net}$ Income $/$ Total Assets $=0.05$;

ROE $=$ Profit Margin*Total Assets Turnover*Equity Multiplier $=0.16 * 0.05 * 4.66=0.037$.

In terms of the ROA and ROE ratio, Pfizer has the highest ROA ratio, so its return on each asset is the highest. The creditors might be interested in Pfizer because its ROA is relatively higher than the other two. The creditors may also be interested in Novartis because Novartis and Pfizer have similar ROA. Merck has the lowest ROA among the three stocks, so its return on assets is not as good as the other two. However, Merck has the highest ROE ratio. ROE ratio consists of three parts, profit margin, total assets turnover, and equity multiplier. Merck has a high ROE ratio because it has a very high equity multiplier, which means it has high debt, and it also shows in the high debt ratio of Merck, so its risk is very high. Pfizer has the second high ROE ratio, and its equity multiplier is not so high, so it has a high return on equity, and investors may interest in it. Novartis has the lowest ROE ratio among the three stocks, but its profit margin is relatively high and it doesn't have a high equity multiplier, so it might attract some investors.

The net earnings of Pfizer is $11,138,000$; the net earnings of Novartis is 7,955,000; the net earnings of Merck is 7,027,000. Pfizer has the highest net earnings and the net earnings of Novartis and Merck are similar.

In general, Pfizer has the best profitability. It has the highest profit margin and highest return on assets. It also has a high return on equity and low risk at the same time. 
Although its total asset turnover is not so high, the other aspects of this stock are better than the other stocks, and it has high net earning too. Novartis has a high return on assets and a relatively high-profit margin, so its profitability is also good, but not as good as Pfizer. But Merck has low profitability, so it is not worth investing in. See Table 2.

Table 2. The Profitability of Three Companies' Stocks

\begin{tabular}{llll}
\hline $\begin{array}{l}\text { Profitability } \\
\text { Ratio }\end{array}$ & $\begin{array}{l}\text { Pfizer Inc. } \\
\text { (PFE) }\end{array}$ & $\begin{array}{l}\text { Novartis } \\
\text { AG (NVS) }\end{array}$ & $\begin{array}{l}\text { Merck \& } \\
\text { Co., Inc. } \\
\text { (MRK) }\end{array}$ \\
\hline $\begin{array}{l}\text { Total asset } \\
\text { turnover }\end{array}$ & 0.3 & 0.4 & 0.36 \\
$\begin{array}{l}\text { Profit } \\
\text { Margin }\end{array}$ & $24 \%$ & $15.59 \%$ & $14.63 \%$ \\
ROA & $7 \%$ & $6 \%$ & $5 \%$ \\
ROE & $17 \%$ & $13.80 \%$ & $26.80 \%$ \\
Net & $11,138,000$ & $7,955,000$ & $7,027,000$ \\
Earnings & &
\end{tabular}

Data source1: https://finance.yahoo.com

\subsection{Market Value}

$\mathrm{PE}$ ratio, $\mathrm{PB}$ ratio, dividend yield, $\mathrm{PEG}$ ratio, momentum, insider buying, and insider holding are the seven factors this paper used to analyze the market value of each stock.

Pfizer

$\mathrm{PE}$ ratio=Earnings per share/Market value per share $=21.10$;

PB ratio $=$ Book Value per Share/Market Price per Share $=3.40$.

Novartis

PE ratio=Earnings per share/Market value per share $=25.84$;

PB ratio=Book Value per Share/Market Price per Share $=4.00$.

Merck

PE ratio=Earnings per share/Market value per share $=27.89$;

PB ratio $=$ Book Value per Share/Market Price per Share $=7.26$.

All three stocks have a $\mathrm{PE}$ ratio that is higher than 20 and have a PB ratio that is higher than 2, so they are all overvalued. However, because all the companies are in the health care industry, so it is normal for them to have a high $\mathrm{PE}$ and $\mathrm{PB}$ ratio, so it is important to analyze other data to help to determine how to make the investment strategy.

\section{Pfizer}

Dividend yield=Cash Dividend per Share/ Current Market Price per Share $=3.92 \%$;

\section{Novartis}

Dividend yield $=$ Cash Dividend per Share/ Current Market Price per Share $=3.63 \%$;

Merck

Dividend yield $=$ Cash Dividend per Share/ Current Market Price per Share $=3.28 \%$.

All three stocks have a dividend yield above 3\%, which means that they are all very mature and stable companies, and they have a great growth prospect. Pfizer has the highest dividend yield, so it is the most valuable stock to invest in.

Pfizer

PEG ratio=Price-to-Earnings Ratio/Growth Rate=0.92;

Novartis

PEG ratio=Price-to-Earnings Ratio/Growth Rate $=1.84$;

Merck

PEG ratio=Price-to-Earnings Ratio/Growth Rate $=1.34$.

In terms of the PEG ratio, only Pfizer's PEG ratio is lower than 1, so it is worth investing in Pfizer because it has a good future growth rate.

In terms of momentum, only Pfizer is a momentum stock, which means that its 50 days moving average is higher than its 200 days moving average, so it might continue to grow in the following months. So, it is worth investing in Novartis and Merck are not momentum stocks, so their 50 days moving average is not higher than its 200 days moving average, and they might not continue to grow in the following months. So, it is not necessary to invest in them.

The insider buying of Pfizer is 1,379,019, and its insider holding is $0.04 \%$; The insider buying of Novartis is 0 , and its insider holding is $0.01 \%$; The insider buying of Merck is 489,717 , and its insider holding is $0.07 \%$. In terms of Insider buying and insider holding. Pfizer and Merck both have insider buying and insider holding, which means that the company's officers or directors have these stocks in their hands. They think these two stocks have the potential to grow and they can get benefit from it. But Pfizer has better performances in Risk and Profitability, and Merck's performances in Risk and Profitability are not very well, so it is worth investing in Pfizer, not Merck. However, Novartis doesn't have insider buying and insider holding, so there is no value to invest in it.

In general, Pfizer has better performance on market value. It is mature, stable, and can continue to grow. See Table 3 . 
Table 3. The Market Value of Three Companies' Stocks

\begin{tabular}{llll}
\hline $\begin{array}{l}\text { Market } \\
\text { Ratio }\end{array}$ & $\begin{array}{l}\text { Pfizer Inc. } \\
\text { (PFE) }\end{array}$ & $\begin{array}{l}\text { Novartis } \\
\text { AG (NVS) }\end{array}$ & $\begin{array}{l}\text { Merck \& } \\
\text { Co., Inc. } \\
\text { (MRK) }\end{array}$ \\
\hline $\begin{array}{l}\text { PE ratio } \\
\text { PB ratio }\end{array}$ & 21.1 & 25.84 & 27.89 \\
$\begin{array}{l}\text { Dividend } \\
\text { Yield }\end{array}$ & $3.92 \%$ & $3.63 \%$ & 3.26 \\
$\begin{array}{l}\text { PEG ratio } \\
\text { Momentum }\end{array}$ & 0.92 & 1.84 & 1.37 \\
$\begin{array}{l}\text { Insider } \\
\text { buying }\end{array}$ & $1,379,019$ & $0.00 \%$ & 489,717 \\
Insider & $0.04 \%$ & $0.01 \%$ & $0.07 \%$ \\
holding & $0.04 \%$ & No \\
\hline
\end{tabular}

Data source1: https://finance.yahoo.com

\section{CONCLUSION}

All in all, Pfizer has low risk, high return, and good market value. Therefore, Pfizer's stock is superior to the other two companies in terms of solvency, profitability, and growth ability. This paper believes that Pfizer is a good investment target in the Healthcare industry of the U.S. stock investment market, and investors who are interested in overseas medical and health investment can pay attention to it.

This paper studies the rapidly developing Healthcare industry makes up for the lack of domestic research on value investment in the Healthcare industry and the neglect of foreign Healthcare industry and widens the theoretical basis of value investment theory by using financial analysis and fundamental analysis, broaden the research background of value investment theory by analysis the Healthcare industry, and increase the research object of value investment theory by using foreign listed companies as examples.

This paper proves that stock selection based on value investment theory is feasible for the Healthcare industry in China and abroad. This article reveals the advantages and disadvantages of foreign Healthcare companies, which can be used as a reference to encourage the development of domestic Healthcare companies, and provides advice for the government, companies, and individual investors. For the government, the government should guide the Healthcare enterprises to carry out reform, optimize the industrial structure, formulate relevant policies and encourage enterprises to carry out innovative development. For domestic Healthcare companies, they should also pay more attention to their asset utilization, enhance their solvency and improve their profitability. This paper also provides index stock selection suggestions for investors who pay attention to the value investment in the Healthcare industry and foreign Healthcare industry. For individual investors, they should pay attention to value investment theory in stock selection to obtain long-term and stable income.

\section{REFERENCES}

[1] Wu Tingting. An Empirical Study on value investment strategy based on financial and valuation indicators [D]. University of science and technology of China, 2015.

[2] $\mathrm{Hu}$ Hongliang. Research on the application of financial indicators based on value investment [D]. Lanzhou University of Technology, 2015.

[3] Xu Hongyi. China stock market value investment strategy and case analysis -- Taking Guizhou Maotai as an example [D]. Zhejiang University, 2019.

[4] Sha Yun. Institutional value investment strategy and empirical analysis based on fundamental information [D]. Fudan University, 2016.

[5] Yi Zuqiong. An empirical analysis on the application of value investment strategy in China's stock market [D]. East China Normal University, 2016.

[6] Cheng Xi. Theory and demonstration of quantitative value investment in China's stock market -- Taking the pharmaceutical and biological sector as an example [D]. Chongqing Technology and Business University, 2020.

[7] Huang Jianhuan, pan Liqin, song Haitao. Don't Chinese investors pay attention to value investment [J]. business research, 2015, 61 (009): 64-70

[8] Gan Weiming, Zhang Dixin. Empirical Study on value investment based multi factor pricing model in China's capital market $[\mathrm{J}]$. Economic longitude and latitude, 2018, 35 (004): 136-140

[9] Peng Xiaojie. Investment strategy optimization of long-term investors in China's capital market [J]. Jiangxi Social Sciences, 2016, 36 (01):62-67.

[10] Lang Ping. Research on enterprise value evaluation based on financial statements -- Taking Yili shares as an example [D]. Hefei Polytechnic University, 2020.

[11] Chu Xiaoxia. Research on long-term value investment of pharmaceutical listed companies [D]. Shanghai Jiaotong University, 2017.

[12] Yang Fangfang. Investment value analysis of Listed Companies in medical information industry [D]. Guangxi Normal University, 2019. 